\title{
PERANCANGAN PROTOTIPE KENDARAAN LISTRIK BERODA TIGA
}

\author{
Didi Widya Utama'), Jan Antonius ${ }^{1)}$ dan R. Danardono A.S. ${ }^{2)}$ \\ ${ }^{1)}$ Program Studi Teknik Mesin, Fakultas Teknik Universitas Tarumanagara \\ ${ }^{2)}$ Depatermen Teknik Mesin Universitas Indonesia \\ e-mail: didiu@ft.untar.ac.id, Artaniz@ymail.com,danardon@ui.ac.id
}

\begin{abstract}
Pollution levels over time has been increased. One of the causes of the pollution are Internal combustion engine vehicle. In Indonesia, the air pollution produced by motor vehicles approximately 55 micrograms per cubic meter $\mathrm{CO}_{2}$. One of the solution to overcome the pollution problem is to create environmentally friendly vehicles using electric motor. In this paper will discuss about the design of a concept of environmentally friendly personal vehicle, which is used 3 wheel and can carry a single passenger. The process is design using the CAD software in three dimensional design, then static analysis was conducted using FEA to produce the maximum stress and the critical location due to the load from the design of the vehicle.
\end{abstract}

Keywords: Frame, stress analysis, prototype electric vehicle

\section{PENDAHULUAN}

Polusi udara adalah sebuah isu yang sedang marak dibahas di dunia global. Polusi udara timbul dari berbagai macam asap yang ditimbulkan pada asap kendaraan, industri, rumah tangga, dan sebagainya. Di Indonesia penyumbang polusi terbanyak disebabkan karena mesin kendaraan bermotor yang menggunakan bahan bakar [1]. Indonesia tercatat memiliki rata-rata 55 mikrogram per meter kubik $\mathrm{CO}_{2}$, kondisi ini dapat membahayakan kesehatan manusia. Sehingga dalam perkembangan kendaraan bermotor terdapat berbagai macam inovasi teknologi otomotif yang terdapat di Indonesia dengan menghasilkan produk ramah lingkungan. Sebuah ajang bergengsi yakni Shell Eco Marathon adalah sebuah acara yang dibuat oleh Perusahaan minyak dan gas Shell. Acara ini mengajak para mahasiswa dan pelajar untuk berlomba-lomba berinovasi menghasilkan sebuah kendaraan yang hemat bahan bakar. Selain itu para peserta juga akan mengikuti pelatihan dan seminar yang diadakan oleh shell. Sekarang Shell Eco Marathon diadakan di tiga tempat yang mewakili tiga benua, yaitu Asia, Amerika, dan Eropa. Program ini diharapkan dapat menemukan solusi untuk masalah-masalah global yang khususnya ada pada penggunaan minyak bumi. Salah satunya adalah polusi udara yang disebabkan oleh emisi yang dihasilkan dari motor torak.

Salah satu inovasi yang dilakukan adalah berupa penggunaan sumber energi listrik dan melakukan inovasi terhadap kerangka kendaraan dengan menggunakan material alumunium agar menjadi lebih ringan [2]. Selain itu penggunaan rangka dengan menggunakan sistem monoque yang dapat mengurangi vibrasi pada kendaraan tanpa mengkorbankan kekuatan dan kekakuan yang berarti.

Rangka merupakan bagian yang penting karena berfungsi sebagai tempat tumpuan bodi dan beban dari komponen lain pada kendaraan [3]. Rangka dapat dipastikan menahan beban yang umumnya adalah beban statis dan dapat memberi dukungan pada berbagai komponen kendaraan [4]. Untuk mencegah terjadinya kegagalan pada rangka sebelum dimanufaktur, stress analysis berbasis metode elemen hingga dilakukan, sehingga diketahui besar serta posisi stress dan defleksi maksimum yang terjadi dan dapat digunakan sebagai kriteria perancangan [5,6,7]. Dari hasil tersebut, dapat dilakukan perbaikan dan modifikasi rangka guna mengurangi terjadinya defleksi [8].

\section{METODOLOGI PENELITIAN}

Secara umum, metodologi penelitian yang dilakukan ditunjukkan pada Gambar 1. 


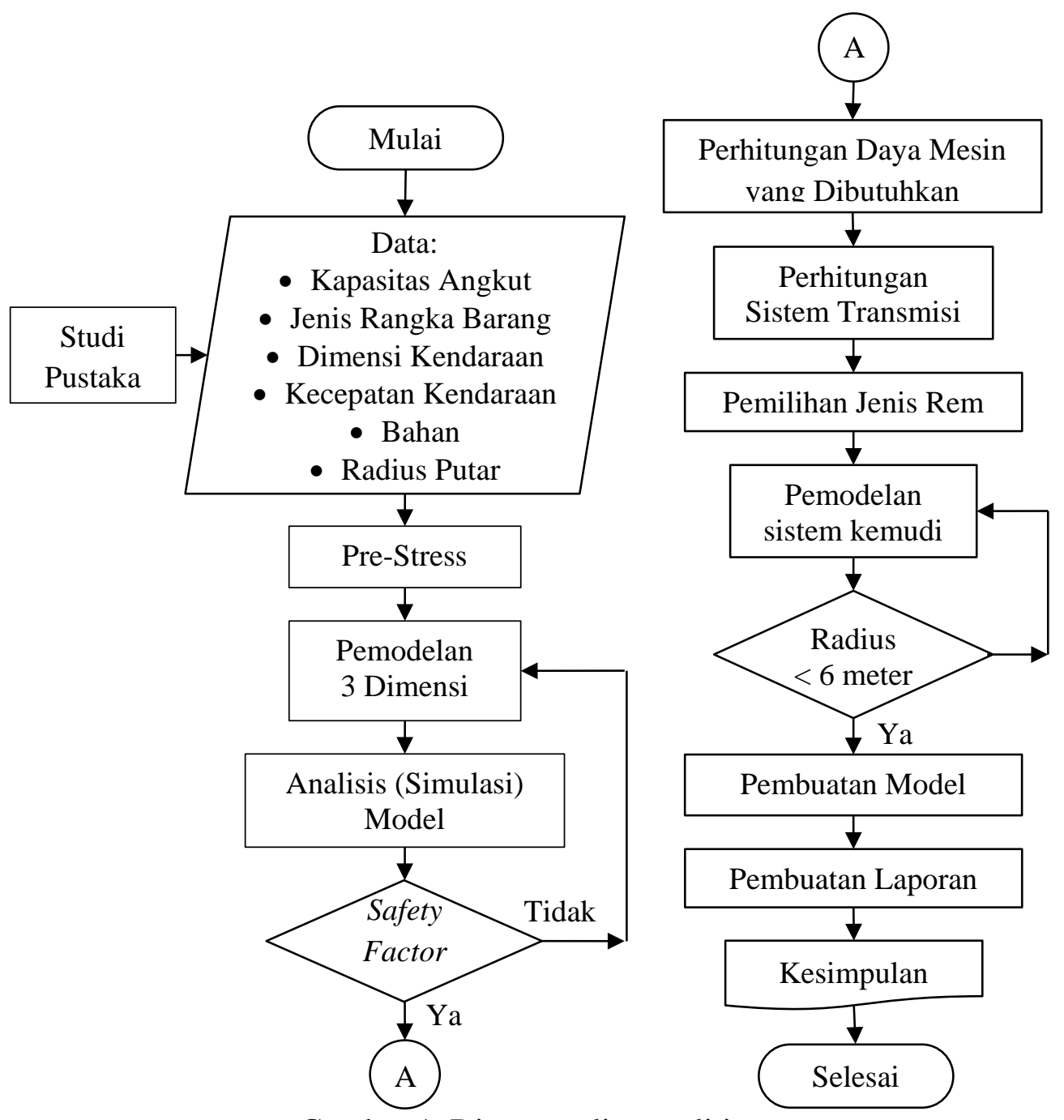

Gambar 1. Diagram alir penelitian
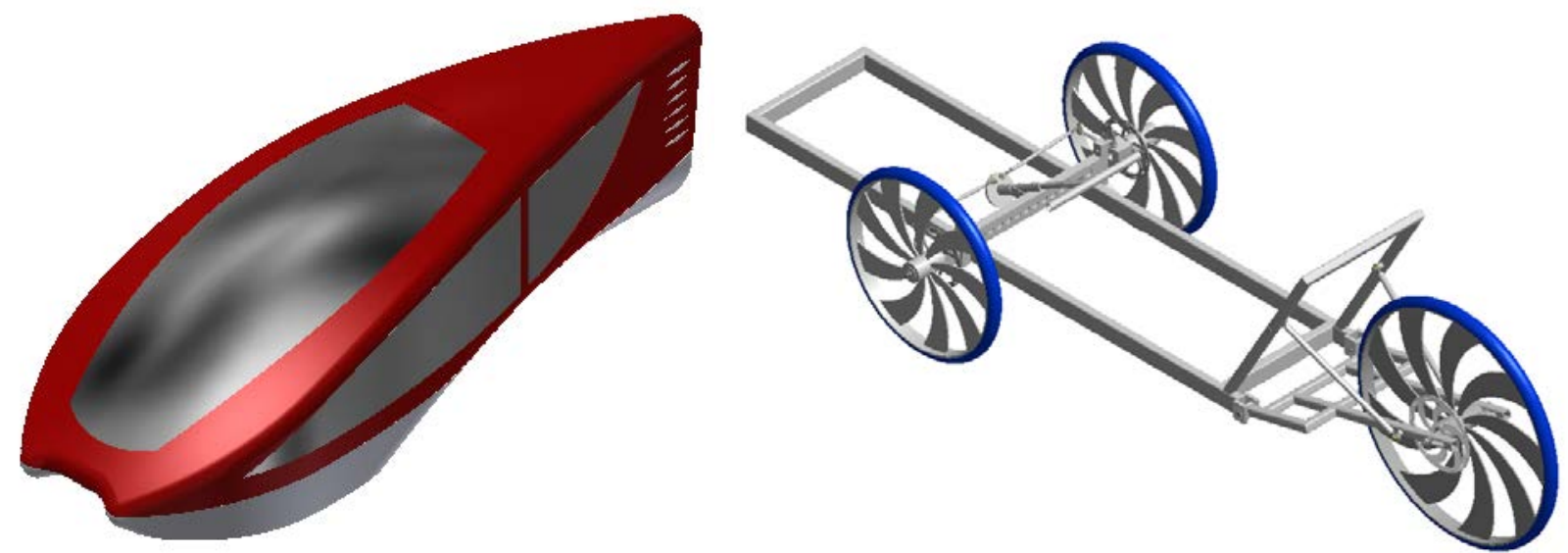

Gambar 2. Pemodelan 3 dimensi prototipe kendaraan listrik bentuk body kendaraan (kiri) dan bentuk rangka dan sistem traksi kendaraan (kanan)

Hasil pemodelan prototipe kendaraan listrik bentuk rangka yang digunakan seperti pada gambar di atas. Pemodelan 3 dimensi konsep rancangan awal, kemudian dilakukan simulasi. Dengan konsep awal rancangan rangka, kemudian dilakukan optimasi pada rangka kendaraan tersebut dengan mengubah posisi bagian tengah rangka yang berbeda. Hal ini disebabkan bahwa bentuk profil yang berbeda akan berpengaruh terhadap tegangan serta defleksi yang dialami rangka. 
Untuk posisi pembebanan dan batasan pada kendaraan, ditunjukkan pada gambar di bawah.

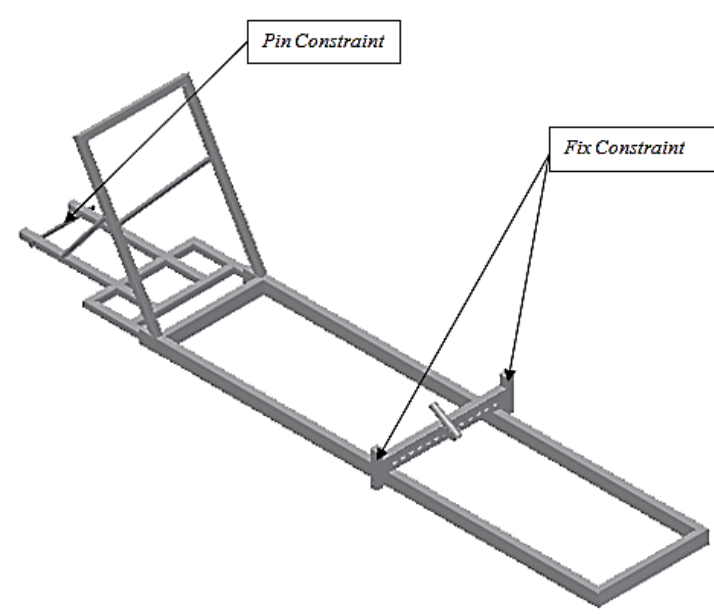

(a)

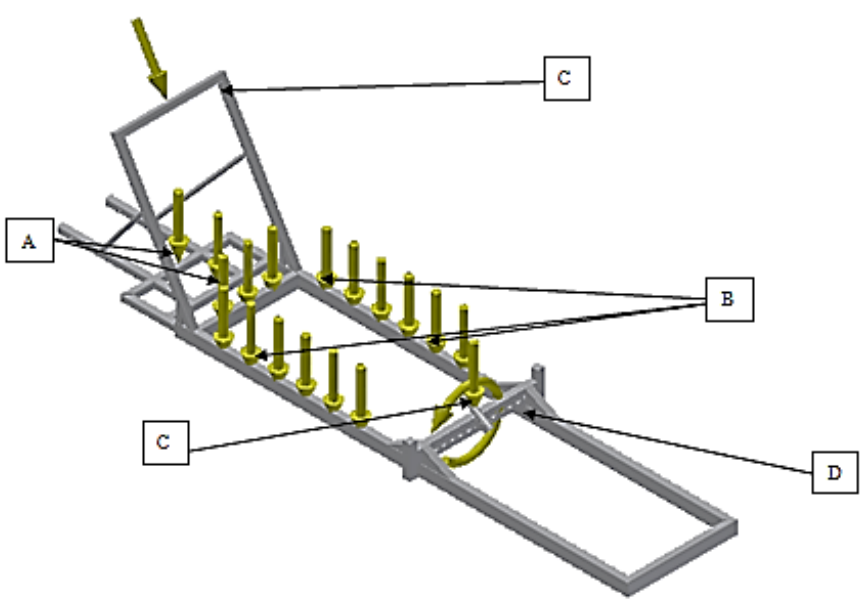

(b)

Gambar 3. Posisi batasan pada kendaraan (a), beban statis pada kendaraan (b)

Gambar 3 (a) menunjukan posisi batasan, dimana pada posisi tersebut adalah tempat pemasangan axle bagian depan kendaraan dengan menggunakan dan poros roda pada bagian belakang kendaraan dengan menggunakan pin constrain. Sementara pada gambar 3 (b), adalah detail pembebanan, yang terdiri dari (B) beban pengemudi $60 \mathrm{~kg}$; (A) beban baterai 5 kg; (A) beban motor listrik $5 \mathrm{~kg}$; (C) beban bodi $10 \mathrm{~kg}$.

Untuk material yang digunakan adalah material aluminium 6061 yang memiliki yield stress $276 \mathrm{MPa}$.

\section{HASIL DAN PEMBAHASAN}

\section{a. Prestress pada rangka batang sederhana}

Pada rangka batang dilakukan Prestress yang berfungsi untuk mengetahui kekuatan digunakan batang berprofil rectangular hollow dengan ukuran tinggi x lebar x tebal: 50 x $25 \times 3$ (mm) dan batang berprofil square hollow dengan ukuran tinggi x lebar x tebal: 25 x 25 x3 (mm). Pemilihan material ini bertujuan untuk mengurangi massa kendaraan yang berlebihan. Metode prestress ini dimulai dengan diberikan pressure pada bagian pinggir batang sebesar 0,045 $\mathrm{MPa}$, dan beban sebesar $750 \mathrm{~N}$ (beban terbesar yang dialami rangka). Pada bagian ujung batang diberikan gaya tekan untuk mengetahui kekuatan batang digunakan.

\section{b. Desain Rangka Kendaraan}

Hasil simulasi rancangan rangka awal yaitu mengalami Von Misses Stress maksimum sebesar 88,36 MPa yang berada pada bagian lokasi titik anti-roll bar atau bagian tengah rangka. Sementara defleksi maksimum terjadi sebesar 2,74 mm pada bagian tengah pengemudi. Hasil perhitungan untuk torsional stiffness menunjukan angka sebesar 10150 Nm/deg. Dengan demikian konsep rancangan rangka awal rangka dinyatakan aman karena mengalami tegangan di bawah nilai yield strength material aluminium, dan kekakuan terhadap torsi di atas rata-rata, yaitu sekitar 10.000 $\mathrm{Nm} / \mathrm{deg}$.

Rangka pada rancangan awal ini memiliki defleksi maksimum yang terjadi adalah 1,057 mm. Defleksi pada konsep rancangan awal ini akan di optimasi untuk menghasilkan rangka dengan defleksi maksimum terkecil 

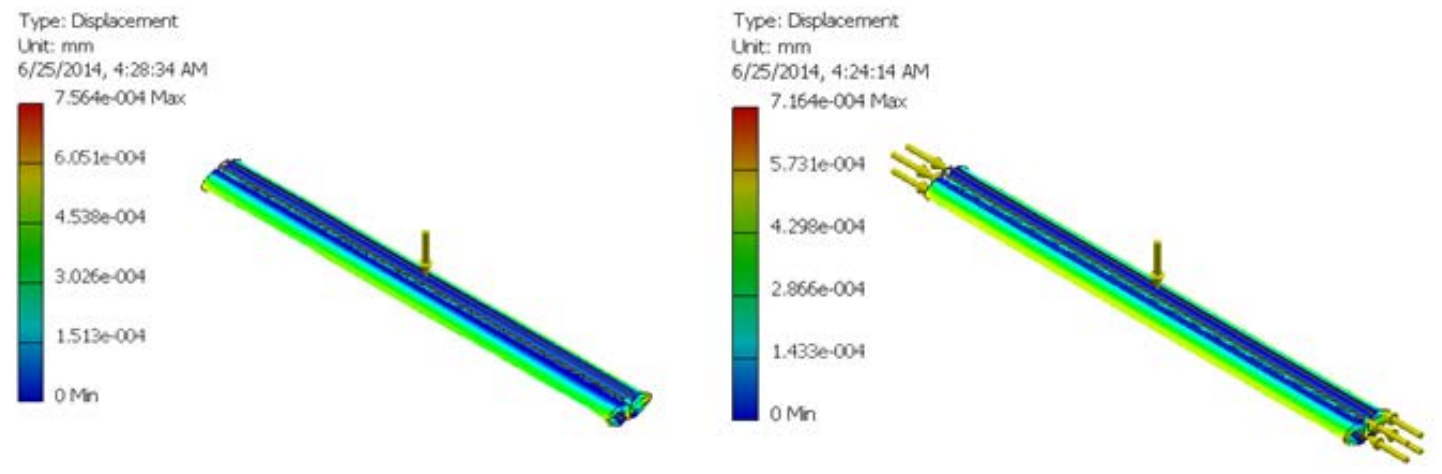

(a)
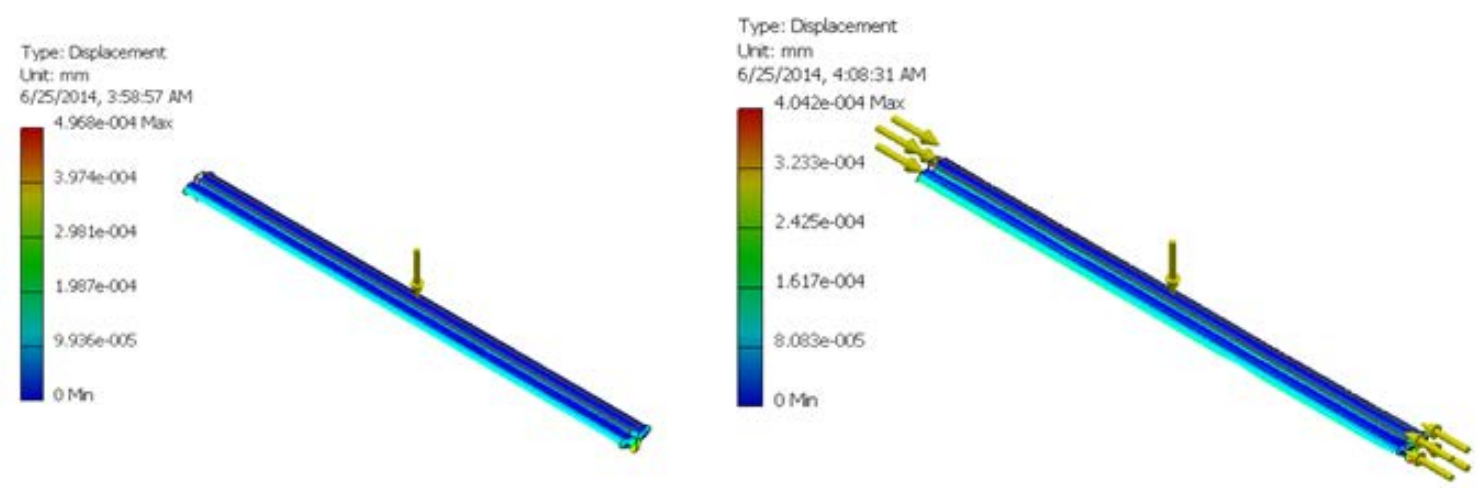

(b)

Gambar 4. Perbandingan defleksi pada batang yang diberikan gaya tekan.

(a) batang berprofil $50 \times 25 \times 3$ (mm), dan (b) batang berprofil $25 \times 25 \times 3$ (mm)
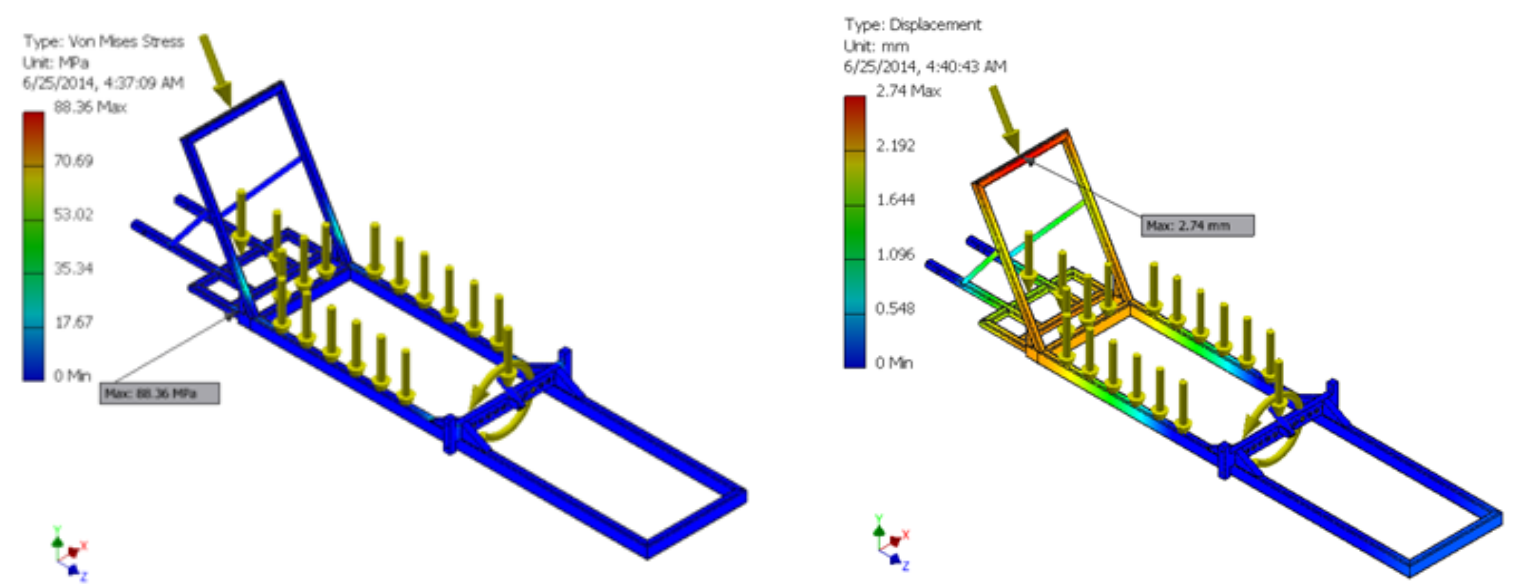

Gambar 5. Von Mises Stress dan defleksi maksimum yang terjadi pada rancangan rangka awal
- Berat Bodi Kendaraan
- Berat Motor Listrik
- Berat Battery
- Berat Pengemudi
- Berat Rangka
- Berat Kendaraan Total

Tabel 1. Data Spesifikasi Kendaraan

$\begin{array}{rlc}10 \mathrm{~kg} & \bullet \text { Kecepatan Maksimum } & 16,67 \mathrm{~m} / \mathrm{s} \\ 10 \mathrm{~kg} & \bullet \text { Jarak Motor Terhadap Roda } & 500 \mathrm{~mm} \\ 5 \mathrm{~kg} & \text { - Ukuran Roda } & 26 \mathrm{in} \\ 60 \mathrm{~kg} & \bullet \text { Jarak Sumbu Kendaraan } & 1250 \mathrm{~mm} \\ 9 \mathrm{~kg} & \text { - Lebar Roda Depan } & 750 \mathrm{~mm} \\ 94 \mathrm{~kg} & \text { - Derajat bebas dari desain kemudi } & 15^{\circ}\end{array}$

Dengan menggunakan data spesifikasi di atas dan rumus usaha maka diketahui;

$$
\mathrm{P}(\text { total })=\mathrm{P}(\text { rolling resistance })+\mathrm{P}(\text { wind })+\mathrm{P}(\text { gravity })+\mathrm{P}(\text { acceleration })
$$




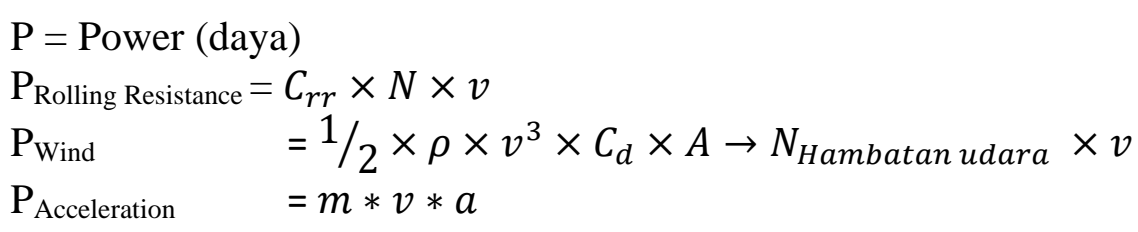

Desain bentuk kendaraan mempertimbangkan koefisien hambatan udara yang minimum, untuk memperoleh hasil nilai hambatan udara pada kecepatan aliran udara sebesar $17 \mathrm{~m} / \mathrm{s}$ dilakukan simulasi virtual wind tunnel yang hasilnya diperoleh drag force sebesar 15,073 $\mathrm{N}$ dan nilai coefficient of drag adalah sebesar 0,15. Gambar berikut ini adalah merupakan hasil dari simulasi virtual wind tunnel.

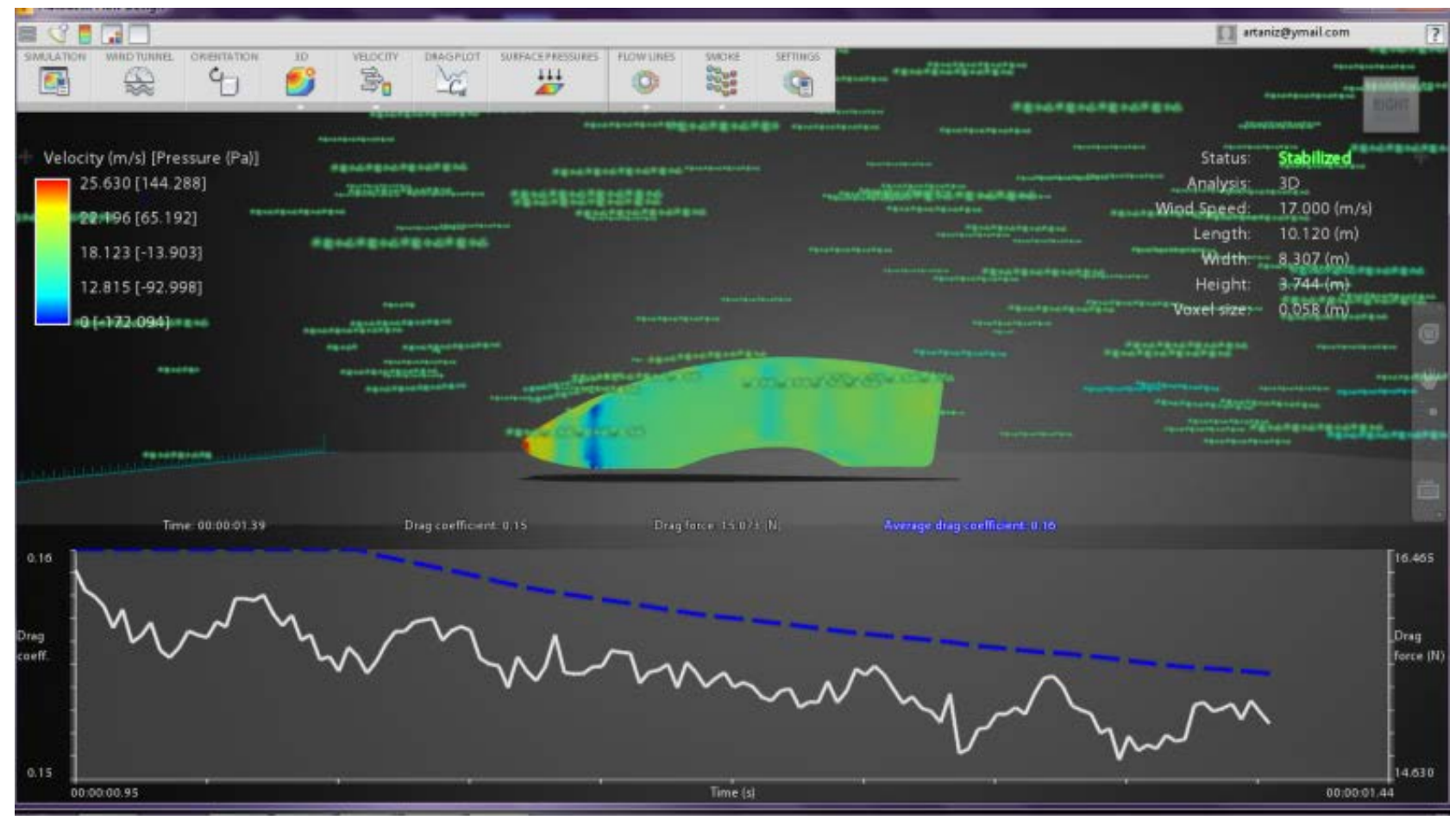

Gambar 6. Gambar grafik drag force hasil simulasi virtual wind tunnel menggunakan perangkat lunak Autodesk Force Effect.

Berdasarkan hasil simulai di atas maka diperoleh:

$$
\mathrm{Cd}=0,15
$$

$v=16,67 \mathrm{~m} / \mathrm{s}$

$N_{\text {hambatan udara }}=15,073 \mathrm{~N}$

$a=0,2 \mathrm{~m} / \mathrm{s}^{2}$

$$
\begin{gathered}
P_{\text {Koifisien gesek }}=\left(94 \mathrm{~kg} \cdot 9,81 \frac{\mathrm{m}}{\mathrm{s}^{2}}\right) \cdot 16,67 \mathrm{~m} / \mathrm{s} \cdot 0,025=384,4 \mathrm{~W} \\
P_{\text {Koifisien udara }}=15,073 \mathrm{~N} * .16 .67 \mathrm{~m} / \mathrm{s}=251,27 \mathrm{~W} \\
P_{\text {Akselerasi }}=94 \mathrm{~kg} \cdot 16.67 \mathrm{~m} / \mathrm{s} \cdot 0,2 \mathrm{~m} / \mathrm{s}^{2}=313,4 \mathrm{~W}
\end{gathered}
$$

$P_{\text {total }}=384,4+251,27+313,4=950 \mathrm{~W}$

\section{c. Sistem Transmisi Kendaraan}

Melalui perhitungan awal maka diketahui kebutuhan motor listrik adalah 1000 watt. Maka motor listrik digunakan adalah sebagai berikut; 
Tabel 2. Spesifikasi Motor Listrik BLDC

\begin{tabular}{cc}
\hline Item & DM8-48100 \\
\hline Power & 1000 \\
\hline Voltage & 48 \\
\hline Rated current & 28 \\
\hline Rated speed & $600-700 \mathrm{r} / \mathrm{min}$ \\
\hline Rated torque & $40 \mathrm{~N} . \mathrm{m}$ \\
\hline Max load & $1200 \mathrm{~kg}$ \\
\hline
\end{tabular}

Untuk mengetahui kecepatan maksimum dari kendaraan maka harus diketahui kecepatan berputar roda. Maka dapat diketahui dengan:

Diketahui:

$$
v=\frac{\pi D N}{60}
$$

$$
\begin{aligned}
& v=60 \mathrm{~km} / \mathrm{h}=1000 \mathrm{~m} / \mathrm{min} \\
& D(\text { Diameter roda })=26 \mathrm{in}=66,04 \mathrm{~cm}=0,6604 \mathrm{~m}
\end{aligned}
$$

Maka,

$$
\begin{aligned}
& v=\frac{\pi D N}{60} \\
& \frac{1000}{60}=\frac{\pi 0,6604 \mathrm{~N}}{60} \\
& N_{2}=482 \mathrm{r} / \mathrm{min}
\end{aligned}
$$

Untuk mencapai kecapatan maksimum maka putaran roda jika langsung dari poros motor listrik akan tidak mencukupi , untuk itu perlu dilakukan penerapan sistem transmisi rantai dengan rasio:

Jika, $\mathrm{N}_{2}=482 \mathrm{r} / \mathrm{min}, \mathrm{N}_{1}=600 \mathrm{r} / \mathrm{min}, \mathrm{P}=1 \mathrm{~kW}=1000 \mathrm{~W}$

Setelah mengetahui kecepatan dari $\mathrm{N}_{2}$, maka rasio kecepatan dari transmisi rantai tersebut dengan:

$$
V \cdot R=\frac{N_{1}}{N_{2}}=\frac{600}{482}=1,245 \approx 2
$$

Maka jumlah gigi pada sproket yang besar adalah;

$$
\begin{gathered}
T_{2}=T_{1} \times \frac{N_{1}}{N_{2}}=27 \times \frac{600}{482}=33.6 \approx 34 \\
\text { Service factor } K_{s}=K_{1} \cdot K_{2} \cdot K_{3} . P=1 \times 1,5 \times 1,5 \times 1=2.25 \mathrm{~kW}=22.500 \mathrm{~W}
\end{gathered}
$$

Dengan data di atas maka mendapatkan nilai standar dari rantai yang digunakan dengan menggunakan standar dari IS : 2403 - 1991 yaitu;
Pitch
$=12.7 \mathrm{~mm}$
Roller diameter
$=8.51 \mathrm{~mm}$
Minimum width of roller $=7.75 \mathrm{~mm}$
Breaking Load
$=17.8 \mathrm{kN}$

Dengan Menggunakan standar tersebut maka dapat di desain sebuah transmisi rantai dengan diameter pitch dari sproket pinion yaitu;

Dan diameter pitch dari sproket besar adalah ;

$$
d_{1}=p \operatorname{cosec}\left(\frac{180}{T 1}\right)=12.7 \operatorname{cosec}\left(\frac{180}{27}\right)=109.34 \mathrm{~mm}
$$

$$
d_{2}=p \operatorname{cosec}\left(\frac{180}{T 1}\right)=12.7 \operatorname{cosec}\left(\frac{180}{34}\right)=137.64 \mathrm{~mm}
$$


Kecepatan radian diameter pitch dari sproket yang kecil adalah;

$$
v_{1}=\frac{\pi d_{1} N_{1}}{60}=\frac{\pi \times 109.34 \mathrm{~mm} \times 600}{60}=3.435 \mathrm{~m} / \mathrm{s}
$$

Beban yang ada pada rantai dapat digambarkan sebagai berikut;

$$
W=\frac{\text { Rated Power }}{\text { Pitch Line Velocity }}=\frac{1}{3.435}=0.3 \mathrm{kN}=300 \mathrm{~N}
$$

Maka, factor of safety adalah $=\frac{W_{b}}{W}=\frac{17800}{300}=60$

\section{d. Sistem Rem Kendaraan}

Dengan mempertimbangkan berat kendaraan, beban kendaran dan kecepatan maka sistem rem yang digunakan pada prototipe kendaraan listrik ini adalah sistem rem yang menggunakan cakram hidrolis. Pemilihan jenis rem ini didasari oleh karakter yang baik dari jenis rem ini untuk kendaraan ringan. Sistem rem ini juga memiliki ketahanan terhadap suhu, dan keadaan lingkungan seperti hujan dan debu. Dengan menggunakan desain sistem rem hidrolis yang baik maka komponen yang dipilih yaitu dengan menggunakan sistem rem hidrolis dari shimano.

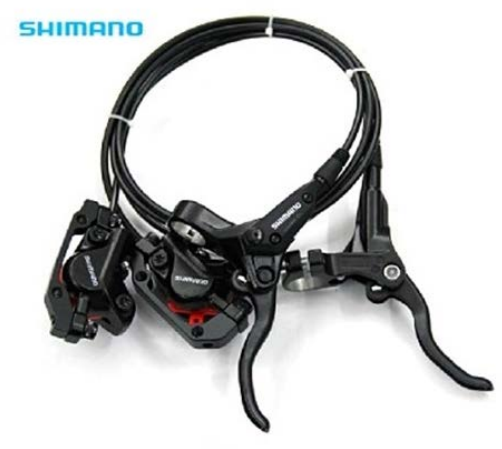

(a)

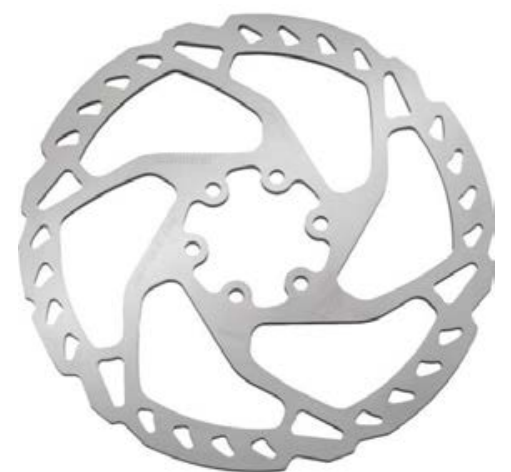

(b)

Gambar 7. Komponen pengereman merk shimano pada kendaraan

(a) Master dengan kaliper rem (b) cakram

\section{e. Sistem Kemudi Kendaraan}

Operasi sistem kemudi pada kendaraan ini menggunakan sistem dari metode ackerman steering geometri. Jenis sistem kemudi ini adalah sistem kemudi yang dinilai stabil pada kecepatan rendah karena mengabaikan faktor dinamis kendaraan hal ini diperlukan karena kendaraan ini difokuskan untuk kecepatan rendah, mudah dibuat, ringan, dan mudah untuk dilakukan penyetelan. Dengan menggunakan sistem ini maka harus jarak sumbu roda harus diukur untuk mendapatkan titik sudut lengan ackerman yang tepat. Sudut ini di dapatkan dengan cara membuat segitiga pada sumbu roda depan terhadap titik sumbu roda belakang.
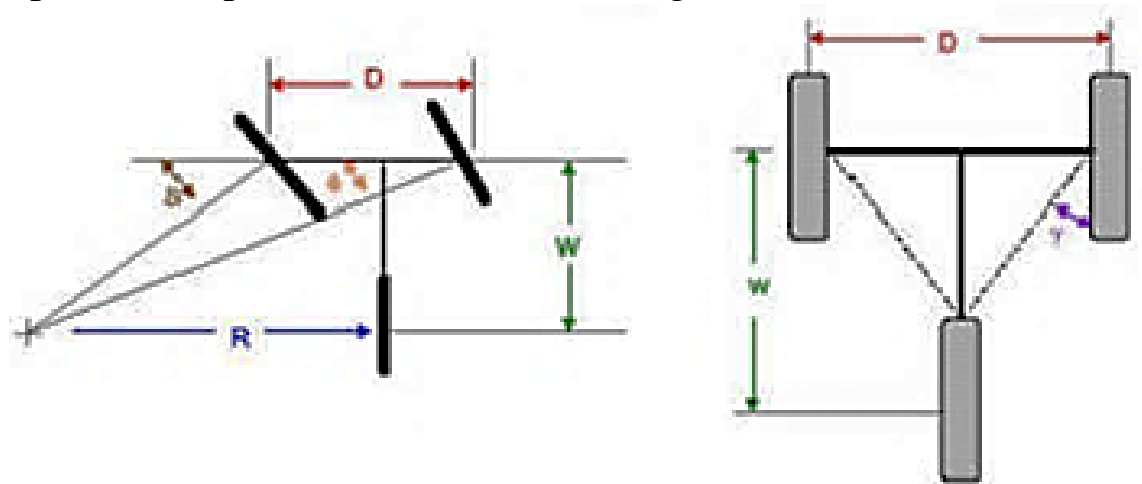

Gambar 8. Sistem kemudi Ackerman pada roda tiga 
Diketahui;

R : Radius putar

W : Jarak Sumbu Roda

D : Lebar antara Roda

$\gamma_{\text {kemudi }}: 15^{\circ}$ (ackerman angle)

Sudut ini dapat dicari dengan menggunakan persamaan:

Maka,

$$
\gamma_{\text {kemudi }}=\arctan \left(\frac{W}{R-\frac{D}{2}}\right)
$$

$$
\begin{aligned}
& \gamma_{\text {kemudi }}=\arctan \left(\frac{1400}{R-\frac{750}{2}}\right)=15^{\circ} \\
& R=5.599,85 \mathrm{~mm}
\end{aligned}
$$

Desain kendaraan harus memiliki radius putar maksimum adalah $6 \mathrm{~m}$, batasan radius putar adalah diasumsikan kendaraan dapat mendahului kendaraan lainnya pada kondisi jalan raya pada umumnya, maka dari hasil radius putar teoritis yang didapatkan $5.59 \mathrm{~m}<6 \mathrm{~m}$, maka desain memenuhi syarat.

\section{KESIMPULAN}

Dari hasil perhitungan dan simulasi pada proses perancangan kendaraan prototipe ber penggerak motor listrik maka dapat di simpulkan bahwa desain adalah aman. Berdasarkan hasil simulasi Virtual wind tunnel Bentuk body kendaraan mempunyai nilai koefisien of drag sebesar 0,15. Desain rangka kendaraan masih memenuhi batas tegangan dan defleksi yang diijinkan, sistem daya/penggerak kendaran dipilih dengan menggunakan motor listrik jenis BLDC ber daya 1kW, dengan sistem transmisi yang harus dibangun untuk memenuhi kecepatan kendaraan yang diinginkan. Sistem pengereman dinilai cukup mampu dan aman untuk mengurangi dan menghentikan kendaraan dari kecepatan maksimalnya, sistem kemudi secara teoritis dapat mengakomodir radius putar yang ditentukan.

\section{DAFTAR PUSTAKA}

[1] James Larminie and John Lowry, Electric Vehicle Technology Explained. UK: John Wiley \& Son, Ltd., 2003.

[2] Zika Zakiya. (2012, Juni) National Geographic Indonesia. [Online]. http://nationalgeographic.co.id/berita/2012/06/teknologi-hybrid-berperan-besar-turunkanpolusi-udara

[3] Noor Eddy, "Analisa Struktur Chassis Kendaraan Serbaguna untuk Perkebunan," in Seminar Nasional Mesin dan Industri, Jakarta, 2009.

[4] Toto Triantoro and War'an Rosihan, "Analisis Kekuatan Chassis Gokart Tipe Kadet Hasil Modifikasi dengan Menggunakan Program Berbasis Finite Element Analysis (FEA)," in Seminar Nasional Mesin dan Industri, Jakarta, 2009.

[5] Roslan Abd Rahman, Mohd Nasir Tamin, and Ojo Kurdi, "Stress Analysis of Heavy Duty Truck Chassis as A Preliminary Data for Its Fatigue Life Prediction Using FEM," Jurnal Mekanikal, vol. 26, pp. 76-85, 2008.

[6] N.K. Ingole and D.V. Bhope, "Stress Analysis of Tractor Trailer Chassis for Self Weight Reduction," International Journal of Engineering Science and Technology, vol. 3, pp. 72187225, 2011.

[7] Patel Vijaykumar V and R.I. Patel, "Structural Analysis of Automotive Chassis Frame and Design Modification for Weight Reduction," International Journal of Engineering Research \& Technology, vol. 1, no. 3, 2012. 
[8] M.S.M Sani et al., "Stress Analysis and Modal Transient Response of Car Chassis," in International Conference on Advance Mechanical Engineering, Selangor, 2009.

[9] Mehrdad Ehsani, Yimin Gao, and Ali Emadi, Modern Electric, Hybrid Electric, and Fuel Cell Vehicles: Fundamentals, Theory, and Design. New York: Taylor and Francis Group, LLC., 2010.

[10] Owen Duffy. (2012, September) Owen Duffy's Web Page. [Online]. http://transportation.centennialcollege.ca/oduffy/Trailers/Level\%201/Frames\%20handout.pdf

[11] Jason C. Brown, A. John Robertson, and Stan T. Serpento, Motor Vehicle Structure: Concepts and Fundamentals. Oxford, UK: Butterworth-Heinemann, 2002. 